\title{
The legal street: a scarcity approach to urban open space in mobility transitions
}



\author{
Brett J. M. Petzer ${ }^{*}(\mathbb{D}$, Anna J. Wieczorek and Geert P. J. Verbong
}

\author{
* Correspondence: b.j.m.petzer@tue. \\ $\mathrm{nl}$ \\ Faculty of Industrial Engineering \\ and Innovation Sciences, Eindhoven \\ University of Technology, \\ Eindhoven, The Netherlands
}

\begin{abstract}
An urban mobility transition requires a transition in space allocation, since most mobility modes are dependent on urban open space for circulation and the storage of vehicles. Despite increasing attention to space and spatiality in transitions research, the finite, physical aspects of urban space, and the means by which it is allocated, have not been adequately acknowledged as an influence on mobility transitions. A conceptual framework is introduced to support comparison between cities in terms of the processes by which open space is (re-)distributed between car and bicycle circulatory and regulatory space. This framework distinguishes between regulatory allocation mechanisms and the appropriation practices of actors. Application to cases in Amsterdam, Brussels and Birmingham reveal unique relationships created by the zero-sum nature of urban open space between the dominant automobility mode and subordinate cycling mode. These relationships open up a new approach to forms of lock-in that work in favour of particular mobility modes within the relatively obdurate urban built environment. Empirically, allocation mechanisms that routinise the production of car space at national level within the EU are shown to be far more prevalent than those for bicycle space, highlighting the constraints faced by radical city-level policies aimed at space reallocation.
\end{abstract}

Keywords: Sustainable mobility, Urban space, Bicycle parking, Space distribution, Parking policy

\section{Science highlights}

- We introduce the legal street method for comparing space allocation processes in different cities from a transitions perspective

- Amsterdam, an example of a city that has achieved success in the transition towards a more sustainable urban mobility system, is shown to incorporate a scarcity-based approach to space allocation

- Scarcity-based approaches are attempted in radical new policies in Brussels and Birmingham, but diluted by residual space entitlements, especially at national level

- Across the EU, mechanisms that allocate open urban space to cars remain far more prevalent than those for bicycles

(C) The Author(s). 2021 Open Access This article is licensed under a Creative Commons Attribution 4.0 International License, which permits use, sharing, adaptation, distribution and reproduction in any medium or format, as long as you give appropriate credit to the original author(s) and the source, provide a link to the Creative Commons licence, and indicate if changes were made. The images or other third party material in this article are included in the article's Creative Commons licence, unless indicated otherwise in a credit line to the material. If material is not included in the article's Creative Commons licence and your intended use is not permitted by statutory regulation or exceeds the permitted use, you will need to obtain permission directly from the copyright holder. To view a copy of this licence, visit http://creativecommons.org/licenses/by/4.0/. 


\section{Policy and practice recommendations}

- Legacy allocations of space that favour and support automobility should be problematised through the lens of space scarcity

- The limits of city-based policy should be considered in the context of national mechanisms that protect space entitlements and routinised space allocation for the dominant automobility mode

- A zero-sum, scarcity-based approach to urban open space should seek to remove the a priori, routinised allocation of space through regulatory devices such as parking minimums, in favour of a level playing field for space claims

\section{Introduction}

A number of cities worldwide have resolved to initiate a transition towards sustainability (UN Habitat 2013; Loorbach 2016). Such a transition implies radical changes in the way cities organise vital systems, such as urban mobility (Frantzeskaki et al. 2017). In this sector, a transition away from a present dominated by fossil-fuelled private automobility has proceeded unevenly and slowly, despite political commitments, scientific imperatives and many bottom-up initiatives (Banister 2005; Hebbert 2005; Castán Broto 2015; Cidell and Prytherch 2015; Hoffmann et al. 2017).

In this paper we argue that this process is difficult partly because an urban mobility transition implies an urban space transition, since automobility, in common with most mobility modes, is highly dependent on access to the open space required both to move and to store vehicles (Prytherch 2015). For this reason, we focus on spatial aspects of sustainable urban mobility, which have received relatively little attention in comparison with themes such as low-carbon propulsion systems, automated driving and shared mobility (Banister 2008).

Urban open space is subject to contestation between various mobility modes and other land uses, all of which make overlapping claims on it that must be reconciled within the finite envelope of open urban space (Cidell and Prytherch 2015). This process has yielded what Prytherch (2018, p. 19) terms a "legal geography" of the street, referring not only to legislation but to the full set of regulations, policies, practices and laws, across all levels of government from international law to neighbourhood zoning, that physically apportion and distribute physical space in a way that codifies urban open space into familiar categories like 'roadway' and 'sidewalk'. Here, we adopt and compress this term as the legal street to refer to the physical product of these regulations and practices, namely, the allocation of uses within urban space. By 'allocation', we refer essentially to the relative distribution of designated spaces within the envelope of urban open space, rather than the means by which that (regulatory) distribution is communicated or expressed (that is, through signage, visual markings, physical infrastructure, paving and surfacing, etc.).

The close relationship between space and mobility systems sets it apart from other socio-technical systems that have been analysed by transitions scholars, requiring a different approach from that developed in transitions research to date (Monstadt 2009, p. 1931). Transitions research offers sophisticated means of analysing these mode-specific factors and their linkages to contexts beyond the scale of the city, that complement the more descriptive and place-bound approach prevalent in urban disciplines (Norton 
2011; Cidell and Prytherch 2015; Wells and Xenias 2015; Prytherch 2018). However, researchers have identified limitations within transitions research's current capacity to move beyond a focus on single systems towards multi-system interactions in areas such as land use, as well as its capacity to address "spatial-institutional challenges" concerned with the systemic configuration of urban areas (Wolfram et al. 2016). These factors are particularly significant for analysis of the inherent physical aspects of urban open space, which is typically governed in a highly fragmented way, with historical divisions between road building and maintenance, and traffic management; between public and private mobility; and between each mobility mode (Crozet et al. 2019). Transitions research would thus benefit from more detailed conceptualisations of the role that space allocation and contestation play in mobility transitions.

We therefore draw on literature that takes urban open space as a primary unit of analysis, from urban disciplines such as spatial planning, law, history and economics. We find that key works in this tradition share foundational assumptions about the nature of this space, namely that it is exhaustible, finite, and subject to overlapping space claims (Shoup 2011; Longhurst 2015; Nikolaeva 2017; Shill 2019). Empirically, case studies in this literature confirm that these factors, which we summarise as the 'scarcity' of space, are highly influential in shaping the political struggles that attend cities' efforts to transform their mobility systems away from car domination, and towards a greater role for public and active transport (that is, cycling, walking and wheelchair use) (Henderson 2015; Longhurst 2015; von Schönfeld and Bertolini 2017). These literatures also share a broad agreement that claims on physical urban space are mediated by multiple forms of regulatory lock-in that are particular to each mobility mode and urban use, such as parking minimums, pedestrian design guidelines and traffic impact assessments (Barter 2015; Rohracher and Späth 2017a). Because open space plays a central role in cities, these urban disciplines have produced an extensive literature supporting the claim that the systemic reallocation of urban space towards automobility has been an essential, and often overlooked, factor in its dominance. These analyses range in physical scale from the urban (Emanuel 2016; Spinney 2016) to the national (Norton 2011), European (Schipper 2008; Oldenziel and de la Bruhèze 2011) and systemic or global level (Urry 2004).

Based on these insights we propose a framework that introduces a space 'scarcity perspective' to transitions research on urban mobility, and focusses on regulatory mechanisms that allocate space for the parking of automobiles and bicycles. We compare these mechanisms with cycling practices in our primary case study of Amsterdam, one of the world's only large cities with a very high cycling modal share (EC DG MOVE 2017), and the rest of the EU, illustrated by the cases of Birmingham and Brussels. The paper addresses the following research question:

By what criteria are claims on urban space by the automobility and cycling modes judged, and how does this affect urban transitions towards sustainable mobility?

The argument in this paper is structured in the following way: In section 2, we review conceptualisations of urban open space in urban disciplines and transitions research. In section 3, we set out the method employed in this study. In section 4, we present our results, with discussion and conclusions in section 5 . 


\section{Urban open space in transitions research}

Urban space has been addressed in transitions research from early on, in influential studies of socio-technical transformation in land transport (Geels 2005). It has been acknowledged in the growing stream of work on sustainable transport (later, mobility) transitions (Geels 2012; Geels et al. 2012; Epprecht et al. 2014; Ghosh et al. 2016). Urban space has also been addressed in the growing literature on urban sustainability transitions (Geels 2010; Bulkeley et al. 2010, 2014; Frantzeskaki et al. 2017). However, transitions scholars have treated urban space as one component of transitions among many others, obscuring the very particular and potentially unique constraints and forms of contestation that it is subject to. One example of this is found in Geels' mapping of the socio-technical system for modern car-based transport (2005, p. 448), in which the question of the space needed for the car system to operate is subsumed into the category of 'road infrastructure'. The use of the term 'road' here implies that open space has already been allocated for a roadway. This assumption obscures the significant and always contingent allocation of a finite resource towards one set of uses, in this case, a roadway appropriate for car-based transportation, at the expense of others. This contingency, reflected in the constant adjustment and reallocation of urban open space over time, ${ }^{1}$ and the sustained public contestation that accompanies it, sets urban open space well apart from other components of socio-technical systems. Before reviewing this conceptualisation of urban space in greater detail, it is useful to contrast it with a broader current of transitions literature that addresses space in general.

Early studies in this stream (Zijlstra and Avelino 2012; Coenen and Truffer 2012; Raven et al. 2012) explicitly responded to claims that transitions research lacked spatial sophistication or precision (Whitmarsh 2012) by drawing on geographical (Hansen and Coenen 2015) and New Mobilities scholarship (Sheller and Urry 2016; Affolderbach and Schulz 2016). These studies seek to 'spatialise' transitions by incorporating space into transitions frameworks as both locus and focus of transitions. This means reconceptualising space as not only physical - a site or container within which transitions occur - but as a dimension of transitions in itself, one that has causative power and is relationally constructed by actors and institutions (Coenen and Truffer 2012; Wieczorek et al. 2015). This project is ongoing, and has yielded a rich account of space in dialogue with other spatial disciplines (Becker et al. 2016; Caprotti and Harmer 2017; Levin-Keitel et al. 2018). However, it is limited in its ability to articulate space as a physically finite resource that lies within and largely constitutes a city, especially given the cumulative, aggregated significance of physical urban open space (streets, sidewalks, square, parking) for transitions in cities, countries and regions.

Instead, conceptualisations of space within transitions research have hitherto been defined by their lack of reckoning with physical constraints, such as exhaustibility or finite carrying capacity. When space is conceptualised in physical terms in this literature, (for example, to explain the unevenness of transitions in Coenen and Truffer 2012) it is implicitly presented as a kind of infrastructure defined by notions of connectivity, reach and proximity (Hodson et al. 2012; Bulkeley et al. 2014), or as a set of scales within a multi-scalar framework (Raven et al. 2012).

${ }^{1}$ Examples of this include the addition or removal of car parking spaces, the creation of bus or bicycle lanes, the conversion of streets to one-way traffic, the widening of roadway or sidewalks, the pedestrianisation of streets, as well as network-level effects like selective permeability. 
Despite this general observation, references to the significance of physical urban open space as a determinant of urban mobility transitions can be found across the literatures that focus on some combination of the themes cities, sustainability, and mobility. However, these empirical observations tend towards an indirect or incomplete analysis of this relationship, in which it is often treated as one component among many.

For example, to return to Geels (2005), he notes that the rise of mass automobility in the USA in the early twentieth century entailed the systematic codification of urban open space into new categories such as 'roadway' and a residual 'sidewalk'. The codification of space for mass automobile storage enabled an additional step, that of commodification, or the development of a market for the sale and rental of car 'parking' spaces. Geels notes that congestion, or the saturation of roadway space, produced regulatory responses that would be widely exported and copied wholesale to other contexts with the global spread of automobility (Geels 2005, pp. 458-459). Later, Geels observes that globally subaltern mobility regimes, such as cycling and walking, compete for urban open space on terms that are less favourable than those that apply to the dominant automobility regime (Geels 2012, p. 475), and refers to the physical constraints of road space as a 'crack' in the (relatively space-hungry) automobility regime. Geels $(2005,2012)$ thus acknowledges that urban open space is finite, that it has been codified and commodified by historical processes, and that it is contested on unequal terms by different mobility regimes, resulting in an uneven, "constructed scarcity" (Nikolaeva 2017).

In contrast to case studies focused on a single socio-technical system, Rohracher and Späth (2017b) represent a stream of transitions research that takes the city as a unit of analysis, extending this 'scarcity perspective' on urban open space to acknowledge that it is contested by very heterogeneous sets of claims extending beyond a single sociotechnical system. Their model of the city as an 'arena' for low-carbon transitions sees multiple levels of governance (metropolitan, global), multiple functional subsystems (mobility, tourism), and multiple actor constituencies intersecting in close proximity. Moreover, they view cities as subject to collective commitments that belong less to the 'landscape' level of particular socio-technical systems, than to the city's own emergent policies or strategies (2017b, p. 291), such as a transition towards carbon neutrality. Rohracher and Späth operationalise this approach through Jensen et al's concept of the 'junction' (2015). A junction is a place-specific catalyst or mediator of change processes that extend across different infrastructure systems, logics and visions through a conflictual process or 'trial of force' (Latour 1987).

In contrast with the more abstract treatments of space within transitions research as a whole, the two streams discussed above, which take socio-technical systems and cities respectively as their unit of analysis, succeed only partially in capturing a scarcity perspective on urban open space. The first stream treats urban space scarcity as just one aspect of transition among others, obscuring the fact that because this kind of space is measurable and finite, it is subject to zero-sum allocations, meaning that a lock-in for one use of space necessarily 'locks out' others. However, transitions literature does not provide an adequate means of conceptualising this lockout, which is distinct from the definition of technological lockout (Schilling 1998). While the second stream acknowledges that urban space is contested by a diversity of claimants, the conflict, competition and 'trials of force' that take place within a 'junction' are (1) inherently exceptional, 
since junctions arise from novel configurations and place-specific projects, and (2) not inherently zero-sum, since the contestation within the junction can arise from any source. We argue, however, that the contestation of urban open space is animated precisely by its routine nature (as in the case of parking minimums) and inherent zerosum competition. Sengers and Raven (2015) capture this zero-sum aspect in their spatial analysis of attempts to introduce the Bus Rapid Transit (BRT) niche in various cities. Unlike, perhaps, energy or water infrastructure, the logic of an intersection means that street-level mobility systems are 'rivalrous', meaning that they can only enable mobility for some by requiring the simultaneous immobility of others. ${ }^{2}$ The works reviewed above reveal that, while 'space' has received growing attention within sustainability transitions research, this literature does not, as yet, offer a means of directly and fully conceptualising the most salient aspects of urban open space, namely that it is finite and exhaustible, and subject to contestation through the overlapping, often rivalrous space claims of rival mobility modes and a multitude of other urban uses. This means that a powerful source of lock-in remains unarticulated, namely the zero-sum nature of the distribution of urban open space, combined with the unequal dynamics by which it is contested. This spatial embedding (Bridge et al. 2013) of dominant modes over subaltern ones through both current allocation practices, and the legacy of historical allocation, is the focus of our empirical research.

The process of commodification of dormant space for automobiles, which has been an influential component of street design across the motorised world, has been studied and critiqued by Shoup (2017) and others (Barter 2015; Groote et al. 2016). Dormant cycling space, or the space used to park bicycles, has also been studied, both as a formal component of the 'legal street' in countries where cycling enjoys institutional support (van der Spek and Scheltema 2015; Heinen and Buehler 2019), and as a more or less transgressive appropriation of space, in contexts in which the bicycle's status is uncertain (Aldred and Jungnickel 2013).

\section{Introducing a scarcity perspective on urban open space}

Movement in cities depends on space for circulation, and vehicle-based forms of transport, such as automobile driving and bicycling, further require 'dormant space' (Spurling 2019) for vehicle storage. Dormant and circulatory space are, in turn, subtracted from the open public space that is bounded by private property boundaries (Prytherch 2018).

Historically, these kinds of spaces were informally or fluidly defined until the advent of mass urbanisation and mass automobility in many countries through the late 19th and early twentieth century. Mass automobilisation saw the gradual construction of a legal regime (Norton 2011) or 'lawscape' (Philippopoulos-Mihalopoulos and FitzGerald 2008) to govern conflicts arising from intensifying competition for urban space (Hamedinger 2014). This process culminated in an internationally consistent regulatory regime governing and apportioning urban space for the use of automobiles, including global standards for parking spaces, turning geometry, and lane width (Schipper and

\footnotetext{
${ }^{2}$ We acknowledge that urban open space can be and is also shared between, or simultaneously occupied and used by, a diversity of mobility modes and urban activities. However, very different sets of compatibilities between various modes and activities obtain at different speeds and volumes of movement, meaning that modally-specific spaces remain a widespread feature of urban open space.
} 
Schot 2011; Attias 2017). The strong codification of automobile space has been accompanied by the commodification of dormant car space in the form of car parking (Foster and Iaione 2016; Borch 2015). New urban areas created after the advent of mass automobility have tended to reflect the constraints and opportunities of the prevailing automobility system (Newman and Kenworthy 1999), creating a worldwide set of urban forms characteristic of mass automobility (Mäkinen et al. 2015), accompanied by rapidly increasing global sprawl (Barrington-Leigh and Millard-Ball 2020). A significant component of this automobile urbanism has been the spatial embedding of parking requirements into routine processes for the approval of new buildings, in the form of parking minimums. They have been adopted very widely, although with great variation in application and enforcement (Henderson 2009; Shoup 2017).

In contrast to the automobility regime, which is governed and stabilised by international treaty and cross-border travel, other kinds of space in the legal street tend to be far more fluidly defined, and most are bundled within the residual category of pedestrian space. In the large majority of countries in which cycling modal share is very low, bicycles, which lack any functional equivalent to the global, mutually reinforcing regulatory regime of automobile space, are "matter in or out of place" (Aldred and Jungnickel 2013). This means that bicycles are a regulatory category in flux, variously and contingently allocated to car space, pedestrian space and/or their own designed space, sometimes along the length of a single street. Globally, designated circulatory and dormant space for bicycles is a rarity in all but a few countries and cities (EC DG MOVE 2017).

Similarly, pedestrian space tends towards the function of a residual category that collects all non-car mobility modes and uses (Prytherch 2018), retaining many features of the pre-existing commons, or common pool resource, of open urban space (Chatterton 2016). Accordingly, while urban space is 'open', it is far from empty, since it teems with regulatory structure governing the spatial and temporal dimensions of movement and activity (von Schönfeld and Bertolini 2017; Shill 2019). The codification of urban space into differentiated kinds of modally- and functionally-specific spaces is an important component of the 'legal street'. Table 1 summarises these ideas in the form of the 'legal street', which we represent as a conceptual cross-section of urban open space and the means by which it is divided into distinct types of modally-defined circulatory and dormant space. The dividing lines in the table represent regulatory demarcations that vary in kind and in relative strength, such as legislation, city by-laws, property lines, national design guidelines, zoning, and engineering formulae. Within pedestrian space, these lines are dashed, to reflect the relatively fluid or informal demarcation of space between the many modes and activities that share 'pedestrian' space, while the double line represents the kerb, a very widespread physical delimitation of the 'roadway' from residual pedestrian space.

Table 1 Conceptual model of the legal street

\begin{tabular}{|c|c|c|c|c|c|c|}
\hline \multirow{3}{*}{$\begin{array}{l}\text { Private } \\
\text { Property }\end{array}$} & \multicolumn{5}{|c|}{ Urban Open Space } & \multirow{3}{*}{$\begin{array}{l}\text { Private } \\
\text { Property }\end{array}$} \\
\hline & \multicolumn{2}{|c|}{ Vehicle space } & \multicolumn{3}{|l|}{ Pedestrian space } & \\
\hline & $\begin{array}{l}\text { Circulatory } \\
\text { space for } \\
\text { vehicles }\end{array}$ & $\begin{array}{l}\text { Dormant } \\
\text { space for } \\
\text { vehicles }\end{array}$ & $\begin{array}{l}\text { Dormant space for } \\
\text { bicycles and other } \\
\text { non-car vehicles, etc. }\end{array}$ & $\begin{array}{l}\text { Pedestrian } \\
\text { circulation }\end{array}$ & $\begin{array}{l}\text { All other urban open space } \\
\text { uses: seating, consumption, } \\
\text { assembly, etc. }\end{array}$ & \\
\hline
\end{tabular}




\section{Operationalising the legal street}

In this study, we operationalize the institutional order represented by the legal street framework to analyse the means by which it is created and maintained. We acknowledge that this order is not permanent, but in constant flux, shaped by the success of claims that actors make on urban space (Henderson 2009). Drawing on the work of urban scholars who find that urban open space is uniquely well-regulated to meet the spatial requirements of automobility, while other modes are subject to regulation that is typically fragmentary, informal or fluid, we distinguish between two kinds of process: allocation mechanisms and appropriation practices.

In our model, space allocation mechanisms generate claims on public and private space to satisfy the space requirements of a given mobility mode or activity. We consider these mechanisms to be stronger where they create legal obligations; where they are applied routinely and consistently as part of basic city governance; and when they codify and allocate space explicitly. Conversely, mechanisms are weaker when they are non-binding; inconsistently enforced; include many loopholes; or only apply sporadically or exceptionally. Taking Western Europe as an example, car parking norms ${ }^{3}$ have historically been strong, due in part of to their consistency between very divergent national contexts (ITDP 2011; Mingardo et al. 2015) and their embedding over decades in the production of new urban fabric. In contrast, some of the most pronounced differences in European spatial allocation mechanisms can be seen in bicycle parking norms, which are strong only in the Netherlands, Denmark and some German Länder (Pucher and Buehler 2008).

We define a second kind of process in practical terms, as a space appropriation practice, or the observed, actual taking (up) of urban open space by users. While space allocation mechanisms may be strong or weak, space appropriation practices are reflected in data such as mode share, or the occupancy rate of parking infrastructure.

Spatial allocation mechanisms and appropriation practices are necessarily extremely diverse in urban open space at every scale, from the neighbourhood to the supranational. They are also an abstraction and simplification of the complexity of stasis and mobility in cities. However, by differentiating between the allocation and appropriation outcomes within the framework of the physically bounded and finite legal street, it is possible to compare different places to each other through the lens of space scarcity and zero-sum allocation.

This brings to transitions research a more explicit means of capturing the ways in which the finitude of urban space converts the advantages of one socio-technical regime into the disadvantages of every another regime and activity. In so doing, it renders measurable (through mobility and space allocation data) a significant form of lock-in and path dependency that has historically favoured both automobility, and the built environment conceived around automobility's spatial needs (Newman and Kenworthy 1999). This reflects the findings of Mäkinen et al. that successive phases of urban mobility regimes have typical corresponding urban forms, such that "changing urban mobility patterns is difficult as we are not only dependent on cars due to established practices but also due to urban form built around car use" (2015, p. 500).

${ }^{3}$ Car parking norms generally take the form of sets of formulae used to convert certain parameters relating to private and public space (for example, the number of beds in a hotel) into a mandatory minimum provision of dormant car space, on private (off-street) and public (on-street) land (Shoup 2017). 
Our refined framework is set out in Table 2, illustrated with general observations applicable to the European Union as a whole (ECF 2018). Owing to constraints on space and data availability, we focus here in particular on dormant space for automobiles and bicycles, on the relative strength or weakness of their corresponding allocation mechanisms, and on whether mode share (circulatory space) and/or occupancy rates (dormant space) are high or low. Dashed lines reflect the finding that the separation between pedestrian and (especially dormant) bicycle space is seldom clear (ECF 2018; Heinen and Buehler 2019, p. 21), and tends towards the condition of the urban commons that predated mass automobility. The divide shown in this table between strong allocation mechanisms and appropriation practices for automobility only, suggests that the 'scarcity' of urban space does not constrain all claims on space equally, but is mediated by the power of socio-technical regimes. We hypothesise that in certain "sociospatial niches" (Geels 2012, p. 475), claims on space are measured against a different, more consistent interpretation of scarcity - one that is less modally mediated; relatively decoupled from historical accumulations of allocated space; and relatively more integrated into the stated aims of current policy.

\section{Methods}

This study was prompted by the authors' observation that conceptualisations of space across several highly cited papers in transitions studies were of limited utility when applied to urban space as a measurable resource for vehicle movement and parking. In designing a more systematic review of this literature, we further observed that keywords related to physical urban open space were inconsistent across and within journals, and that a small minority of studies attended to space in this sense. These factors guided us towards a snowball citation sampling method (Lecy and Beatty 2012). We started with a thematic analysis of highly-cited papers addressing spatial themes in transitions (Coenen and Truffer 2012; Geels 2012; Raven et al. 2012; Bridge et al. 2013; Sengers and Raven 2015; Becker et al. 2016; Caprotti and Harmer 2017; Levin-Keitel et al. 2018). We continued to add to our sample citations that proved relevant to physical urban space, until saturation had been reached in terms of space conceptualisations within transitions.

Centuries of attention to urban space as a site of exchange and circulation have produced a large literature describing its evolution, codification and commodification in fields such as urban planning, economics, law and history. In consultation with leading

Table 2 Space allocation mechanisms and appropriation practices for the EU as a whole

\begin{tabular}{|c|c|c|c|c|c|}
\hline \multirow{2}{*}{$\begin{array}{l}\text { Type of Space } \\
\text { Type of claim }\end{array}$} & \multicolumn{2}{|c|}{ Automobile space } & \multicolumn{2}{|c|}{ Bicycle space } & \multirow{2}{*}{$\begin{array}{l}\text { Pedestrian } \\
\text { and other } \\
\text { space }\end{array}$} \\
\hline & $\begin{array}{l}\text { Circulatory } \\
\text { space }\end{array}$ & Dormant space & $\begin{array}{l}\text { Circulatory } \\
\text { space }\end{array}$ & Dormant space & \\
\hline $\begin{array}{l}\text { Allocation } \\
\text { Mechanism }\end{array}$ & $\begin{array}{l}\text { Strong - car } \\
\text { access is a } \\
\text { legal pre- } \\
\text { requisite of } \\
\text { building } \\
\text { regulations }\end{array}$ & $\begin{array}{l}\text { Strong - Guaranteed by } \\
\text { parking minimums and } \\
\text { stabilized by } \\
\text { international treaty; } \\
\text { access free or through } \\
\text { payment }\end{array}$ & $\begin{array}{l}\text { Weak - No } \\
\text { wide-spread } \\
\text { guarantee } \\
\text { of access }\end{array}$ & $\begin{array}{l}\text { Weak - No } \\
\text { widespread } \\
\text { regulation of } \\
\text { availability or } \\
\text { dimensions; access } \\
\text { often informal }\end{array}$ & $\begin{array}{l}\text { Weak - No } \\
\text { widespread } \\
\text { regulation or } \\
\text { set of } \\
\text { minimum } \\
\text { standards }\end{array}$ \\
\hline $\begin{array}{l}\text { Appropriation } \\
\text { Practice }\end{array}$ & $\begin{array}{l}\text { Strong - high } \\
\text { overall mode } \\
\text { share }\end{array}$ & $\begin{array}{l}\text { Strong - high } \\
\text { occupancy rate, well } \\
\text { documented as } \\
\text { revenue source }\end{array}$ & $\begin{array}{l}\text { Weak - low } \\
\text { overall } \\
\text { mode share }\end{array}$ & $\begin{array}{l}\text { Weak - lack of data } \\
\text { on occupancy rate, } \\
\text { little to no revenue }\end{array}$ & Mixed \\
\hline
\end{tabular}


mobilities scholars who have published extensively on questions of urban open space, ${ }^{4}$ we were guided towards key works outside of the transitions literature that address questions of urban open space allocation and contestation. Following a snowball process, we added to our sample until saturation was reached in terms of conceptualisations of urban open space as a physical resource, yielding a sample of 20 papers representing the fields of urban planning (8), urban politics (5), urban history (3), urban economics (3), urban law (3), and civil engineering (3) (see Table 3). A comparison of these two sets of space conceptualisations, from transitions research and urban disciplines respectively, resulted in initial conceptualisations of space allocation mechanisms and appropriation practices. A draft of our legal street framework was further submitted to an expert on cycling space contestation in Amsterdam, Prof Ruth Oldenziel, for review and triangulation of the overall framework and the concept of allocation mechanisms and appropriation practices in particular. Amsterdam's status as a socio-spatial niche (Geels 2012) or 'extreme case' (ibid.) in which space reallocation policies have been implemented and developed for decades motivated a structure in which it serves as a primary case to be studied in greater depth (Yin, 2014).

Birmingham and Brussels were selected as secondary cases more representative of European norms (ECF 2018), as two other historically car-dominated cities in which major space reallocation policies are comparatively recent and therefore largely prospective. Birmingham, historically known as the UK's "motorway city" (Gunn 2018), has adopted radical plans aligned with Belgian and Dutch precedents, which aim to rapidly reallocate urban land away from car parking towards housing, public transport and cycling (Birmingham City Council 2019; Reid 2020a, "G" interview 29/09/2020). Brussels, a city known for political fragmentation and the loss of major public spaces and landmarks in favour of motorway-building and institutional campuses (Bruxelles Mobilité 2016a), radical space-reallocation plans have been underway since the late 2000s, and are beginning to deliver visible change, as well as significant contestation ("H" interview, 02/10/2020).

To study allocation mechanisms across all cases, we retrieved applicable regulations from EUR-Lex and reviewed grey literature obtained via web search of city websites, focusing on laws, design guidelines, and applicable city-issued policies, and including relevant academic sources cited in these texts (see Table 4). Appropriation practices for all cases were captured through publicly-available data relating to mobility modal share and parking use rates. Data on allocation mechanisms and appropriation practices was thematically coded in terms of the legal street categories operationalised in Table 2. For all three cases, a total of eight (8) semi-structured interviews were conducted with city officials responsible for space reallocation and bicycle or automobile parking. Questions focused on corroborating the claims and descriptions presented in grey literature and capturing any significant data not included in these texts. For our primary case, the greater maturity and scope of Amsterdam's space reallocation policies prompted supplementary interviews with officials as well as stakeholders from a major cycling charity and neighbourhood organisation engaged in a well-publicised contestation of these policies.

${ }^{4}$ Open-ended interviews were conducted with these scholars: Prof. Marco te Brömmelstroet, Professor of Urban Mobility Futures at the University of Amsterdam; Prof. Ruth Oldenziel, Full Professor in the History of Technology at the Eindhoven University of Technology. 
Table 3 Sources for thematic review of space concepts in non-transitions literature

\begin{tabular}{ll}
\hline Research Area & Journal Articles \\
\hline Urban history & (Norton 2011; Oldenziel and de la Bruhèze 2011; Longhurst 2015) \\
Urban economics & (Fiorito and Kollintzas 2004; Gössling and Choi 2015; Groote et al. 2016) \\
Urban law & (Philippopoulos-Mihalopoulos and FitzGerald 2008; Prytherch 2018; Shill 2019) \\
$\begin{array}{l}\text { Urban politics and } \\
\text { sociology }\end{array}$ & (Henderson 2009, 2015; Becker et al. 2016; Avelino et al. 2016; Ward et al. 2018) \\
Urban planning & (Magalhães and Carmona 2006; Castán Broto 2015; Cidell and Prytherch 2015; Mäkinen \\
& et al. 2015; Brown 2016; von Schönfeld and Bertolini 2017; Adam et al. 2018; Nello- \\
Civil engineering & Deakin 2019) \\
\hline
\end{tabular}

\section{Results}

\section{Legislation and the 'legal street'}

While trans-European road infrastructure is governed by international and European-level agreements; and trunk, primary or through-roads are typically subject to distinct national laws (such as the UK's Design Manual for Roads and Bridges, or Germany's Bundesfernstraßengesetz); urban space, and the roads and streets that serve it, have historically been governed at the local level. This has resulted in sometimes highly heterogeneous regulatory environments (Schipper 2008, pp. 262-274). In most cases, these environments are in themselves a more or less haphazard accretion of rules and practices originating in disparate efforts to control fire, levy tax, prevent disease, etc. As such, it is challenging to cite a definitive set of laws that govern space allocation at local street level, especially as the laws that do exist, tend to define broad parameters and principles, primarily in relation to

Table 4 Data sources for comparative case study

\begin{tabular}{|c|c|c|c|}
\hline \multirow{2}{*}{$\begin{array}{l}\text { Data } \\
\text { sources }\end{array}$} & \multirow{2}{*}{$\begin{array}{l}\text { Primary case } \\
\text { Amsterdam }\end{array}$} & \multicolumn{2}{|l|}{ Secondary cases } \\
\hline & & Brussels & Birmingham \\
\hline Interviews & $\begin{array}{l}\text { "A", Fietsersbond, 13/01/2020; } \\
\text { "B", urban planner, City of } \\
\text { Amsterdam, 17/01/2020; "C", } \\
\text { urban designer, City of } \\
\text { Amsterdam, 22/01/2020; "D", } \\
\text { Vervoerregio Amsterdam, 29/ } \\
\text { 11/2019 }\end{array}$ & $\begin{array}{l}\text { "E", Head of Cycling Policy, } \\
\text { Brussels Capital Region, 30/09/ } \\
\text { 2020; "F", Public Space } \\
\text { Strategic Advisor, 02/10/2020. }\end{array}$ & $\begin{array}{l}\text { 29/09/2020, "G", Head of } \\
\text { Transport Planning, City of } \\
\text { Birmingham; " } H^{\prime \prime} \text {, Principal } \\
\text { Transport Policy Officer, City of } \\
\text { Birmingham, 02/10/2020 }\end{array}$ \\
\hline $\begin{array}{l}\text { Grey } \\
\text { literature }\end{array}$ & $\begin{array}{l}\text { Gemeente Amsterdam [City of } \\
\text { Amsterdam] (2016, 2017a, b, } \\
\text { 2019a, b, c); Metropoolregio } \\
\text { Amsterdam [Greater } \\
\text { Amsterdam metropolitan } \\
\text { transport authority] } \\
\text { (Nieuwstraten 2019). }\end{array}$ & $\begin{array}{l}\text { Bruxelles Mobilité (2016a, b, } \\
\text { 2017, 2020); Bruxelles } \\
\text { Environnement (2019); Pro Velo } \\
\text { (2017); Région de Bruxelles- } \\
\text { Capital; Van Zeebroeck and } \\
\text { Charles (2014) }\end{array}$ & $\begin{array}{l}\text { Birmingham Cycle Revolution, } \\
\text { "Our Journey" (January 2020)"; } \\
\text { Birmingham Parking: } \\
\text { Supplementary Planning } \\
\text { Document, Consultation Draft } \\
(2019)^{\mathrm{b}} \text {; Birmingham City } \\
\text { Council (Birmingham City } \\
\text { Council 2020a, b) }\end{array}$ \\
\hline $\begin{array}{l}\text { Academic } \\
\text { Sources }\end{array}$ & $\begin{array}{l}\text { (Hirschhorn et al. 2019; Buiter } \\
\text { 2008) }\end{array}$ & $\begin{array}{l}\text { (Henry et al. 2020; Hubert et al. } \\
\text { 2017; May 2017) }\end{array}$ & $\begin{array}{l}\text { (Gunn 2018; Hirschhorn et al. } \\
\text { 2019) }\end{array}$ \\
\hline Journalism & (Verkade 2019) & (De Muelenaere 2020) & (Reid 2020a, b) \\
\hline $\begin{array}{l}\text { Legislation } \\
\text { and Design } \\
\text { Guidance }\end{array}$ & $\begin{array}{l}\text { CROW }(2012,2016) ; \text { Wet } \\
\text { ruimtelijke ordening } \\
(\text { BWBR0020449), revised } 2018 \\
(1965)^{c}\end{array}$ & Wegcode [Roads Act] of 1975. & $\begin{array}{l}\text { Manual for Streets } 1 \text { and } 2 \text { (UK } \\
\text { DfT 2007; CIHT 2010). }\end{array}$ \\
\hline
\end{tabular}

ahttps://www.birmingham.gov.uk/downloads/file/15003/birmingham_cycle_revolution_-_our_journey ${ }^{b}$ https://www.birminghambeheard.org.uk/economy/parkingspd/supporting_documents/Parking\%20SPD\%2 Oconsultation\%20FINAL.pdf

chttps://wetten.overheid.nl/BWBR0020449/2018-07-01, consulted 30/08/2020 
automobility only. The technical detail that gives effect to these laws usually resides in manuals and design guidelines that are often advisory (for example, Birmingham's advisory cycle lanes, "G" interview, 29/09/2020). More recently, local and national governments and the EU have responded to this state of affairs with consolidating design guidelines and unifying regulatory frameworks that seek to impose greater consistency on street-level design and space allocation. This process began in the mid-1960s in the Netherlands, and has to date produced several generations of urban form shaped by a consolidated regulatory framework for local streets, while in Birmingham and Brussels, comparable efforts are very recent, with major regulatory changes limited to the past decade-and-a-half. The Netherlands' Wet ruimtelijke ordening (Wro) [Spatial Planning Act], adopted in 1965 and constantly revised since, has imposed a high degree of alignment and integration between street-level design and the urban, regional and national scales, expressed in the ASVV design guidelines (CROW 2012). Since 1997, it has been complemented by the programme Duurzaam Veilig [Sustainable Safety], which has guided a comprehensive redesign of Dutch roads and streets, with relatively strict and nationally consistent distinctions in speed regulation, physical design, and degree of modal separation between local access roads, mixed roads, and through roads. ${ }^{5}$ In the UK, the fragmented nature of street design practices led in 2007 to a major shift in approach with the central government's Manual for Streets (UK DfT 2007), the first such revision in 30 years, with sharply reduced priority for automobility space. In Brussels, a city that only gained meaningful control over its transport planning as late as 1989, primary roads and freeways penetrate into the heart of the city, and a large measure of control over streets rests with 19 municipalities (Région de Bruxelles-Capitale, 2007; Bruxelles Mobilité 2016a). Given this uneven legislative framework, and the significance of heterogeneous nonstatutory elements in the makeup of the 'legal street', we interpret our results using the concepts described in the legal street framework (Table 2), namely automobile, bicycle and pedestrian space; circulatory and dormant space; and spatial allocation mechanisms and appropriation practices.

\section{In the European Union}

The European Union has traditionally regarded urban policy as a matter for member states to govern at the national or local level (EU Partnership on Urban Mobility 2017). In the absence of an EU-wide approach to urban space, a profusion of programmes promoting cooperation, pilot schemes and experimentation at the city and regional level has led to a substantial policy consensus on the importance of a collective urban agenda that can support a sustainable urban mobility transition (EU DG Mobility and Transport 2017). However, we find that this lack of uniform regulation affects bicycle and pedestrian space significantly more than automobile space: less than a third of member states have a national bicycle parking minimum, whereas 5 out of 10 member states continue to impose a strict minimum car parking requirement for new buildings (ECF 2018). A major review by the European Cyclists' Federation (2018) summarises these differences as a stable, relatively consistent system of automobile space allocation mechanisms, particularly due to international treaty agreements, ${ }^{6}$

\footnotetext{
${ }_{5}^{5}$ In Dutch, local access streets are known as erftoegangswegen, mixed roads are gebiedsontsluitingswegen, and through roads are stroomwegen.

${ }^{6}$ At the highest level, these variations within the EU must firstly be understood within international constraints such as the Vienna Convention of 1968, which defines and separates international open public space into a circulatory space for vehicles (the "carriageway"), separate from pedestrian space ("footpaths, pavements or verges") and, where applicable, bicycle circulatory space ("cycle tracks/lanes") (UN 1968).
} 
compared to a mechanisms for bicycle and pedestrian space allocation that are fragmentary, highly localized, inconsistently applied and enforced, and often vague.

\section{Automobile circulatory space}

In the EU, automobile circulatory space is governed by national transport codes subject to significant constraints, such as the regulations governing the Trans-European Transport Network (TEN-T), which include directive 2008/96/EC. These spaces stabilize high-level international links, reinforcing uniformity between national regulations (Schipper 2008), and reflecting the EU average modal split for passenger cars of $81 \%$ (EC DG MOVE 2019).

\section{Automobile dormant space}

Across the EU, only one country, France, sets maximum limits on off-street parking at the national level (ECF 2018), while 9 countries, the Brussels region and several German states impose parking minimums that can be adjusted locally. The remaining majority of states and regions have no national guidelines, or impose strict parking minimums at the national level. ${ }^{7}$ Despite these differences, the overall supply of car parking spaces in the EU is abundant, amounting to an estimate of 47 million regulated (paid) parking spaces, equal to approximately one third of the land area of the Netherlands (European Parking Association 2013, p. 4), at an estimated public subsidy of $€ 300$ per person per year (ECF 2018).

\section{Bicycle circulatory space}

Bicycle circulatory space, much like dormant space, is defined in highly variable terms across EU member states, reflecting the generally low cycling modal share across the vast majority of the EU. This is also attributable to a data gap - at present, the cycling mode share for the EU as a whole is unknown, although a 2014 Eurobarometer survey suggested a figure greater than $10 \%$ in only 7 out of 28 member states (ECF 2017, p. 25). This variation extends from the national network of urban, rural and long-distance cycling routes of the Netherlands and Denmark to a near absence of designated infrastructure in countries like Malta, Cyprus and Portugal, where estimated mode share approaches 0\% (ECF 2017, p. 25).

\section{Bicycle dormant space}

There is no EU-wide standard for bicycle infrastructure of any kind (ECF 2018). Bicycle parking was mentioned for the first time in EU Directives as recently as 2018 (ECF 2018, p. 38). The Energy Performance of Buildings directive, EU 2018/ 844, recommends that member states consider the need for dedicated supporting infrastructure for sustainable transport modes in building regulations, and the interaction between these regulations and mobility; it is non-binding. Overall, bicycle parking space provision is fragmentary, and mechanisms for the allocation of

\footnotetext{
${ }^{7}$ Namely, Bulgaria, Cyprus, Czechia, Italy, Romania, Slovakia, and several Austrian and German states.
} 
bicycle space have little institutional power. ${ }^{8}$ At the national level, more than $70 \%$ of EU member lack binding national regulations or guidelines for bicycle parking. ${ }^{9}$

\section{Pedestrian space}

There are no national regulations governing the provision of open space for pedestrian access and other urban uses on the EU level, although the provision of open and green space is mentioned in various directives and policy documents.

\section{Brussels}

Brussels has long been subject to daily car traffic congestion, and continues to invest in subsidized parking; as recently as 2016, residential parking permits cost $€ 10$ per first car per year, or the price of $2 \mathrm{~h}$ ' on-street parking in the city centre. One of the city's largest public works ever, the large-scale pedestrianisation of a grid of city centre streets, is intended to signal a change of direction to decades of carcentric planning that saw motorways penetrate into central Brussels to support elite flight to the suburbs (Hubert et al. 2017, "E" interview, 30/09/2020). However, this pedestrian and cycling circulatory space remains disconnected from other similar infrastructure by the car-dominated urban fabric that remains. The city of Brussels mandates a bicycle parking minimum only for new-build, multi-unit buildings (ECF 2018, p. 16), while retaining a strict minimum of car parking spaces (ECF 2018, p. 37), although this policy is about to be replaced by far stricter sets of maximums ("H" interview, 02/10/2020). In Brussels, only 55\% of households own a car, yet building regulations have hitherto required a minimum of one new parking space per new apartment. The city plans to increase cycling mode share from 7 to $8 \%$ in 2019 to $20 \%$, and is investing heavily in new purpose-built secure parking facilities, but outside of the city centre. ${ }^{10}$ These investments are accompanied by the expansion of dormant and circulatory car space as well, and in 2016, only $1.5 \%$ of road space was reserved exclusively for bicycles (Bruxelles Mobilité 2016a, p. 73).

\section{Birmingham}

Birmingham's new set of spatial allocation mechanisms are intended to make a dramatic break with the car-dependent present. After decades of parking minimums resulting in highly abundant car parking, the city has moved to audit and review its allocated car circulatory space; set maximums for dormant car space; remove all citycentre on-street free parking; and charge an annual levy on workplace car parking, to encourage their removal and conversion to other uses (Birmingham City Council 2019). Scarcity concepts are cited in the city's new parking plan, which emphasizes that "valuable land in short supply [should be] used in the most productive way possible"

\footnotetext{
${ }^{8}$ Lobbying to promote these claims nationally and EU-wide is at an early stage and calls for the adoption of binding principles for cycling infrastructure that feed through to national and local design standards (ECF 2017, p. 49).

${ }^{9}$ Non-binding regulations exist in Czechia, Estonia, Iceland, Ireland, Latvia, Portugal, Sweden and Switzerland, as well as the regions of Wallonia (BE) and Rhineland-Palatinate (DE). There are no national regulations in Croatia, Finland, Greece, Luxembourg, Malta, Norway, Poland, Romania, Slovakia, Spain and the UK, as well as the regions of Burgenland (AT), Flanders (BE) and Bavaria (DE).

${ }^{10}$ This disjuncture can in part be attributed to the large measure of autonomy that Brussels' constituent municipalities retain in the application of the city government's plans ("H" interview, 02/10/2020).
} 
(Birmingham City Council 2019; Reid 2020a). However, bicycle parking remains scarce, with new cycling parking minimums applicable only to new buildings (Birmingham City Council 2019, p. 31). Spatial appropriation practices currently present a stark contrast with the city's new policy direction. The city's intention is to quintuple cycling mode share from the current level of less than $1 \%$ (2019) to $5 \%$ by 2023 , while an historical overabundance of dormant car space allocation is reflected in the finding that 10,000 car spaces remain unoccupied through the workday in central Birmingham (Birmingham City Council 2019). However, car mode share shows a steady decline since 2013, matched by increasing use of public transport ("G" interview, 29/09/2020).

In summary, the lack of common EU-wide regulations to govern spatial allocation mechanisms for cycling, but not automobility, closely matches the space appropriation practices of Europeans, as evidenced by walking and cycling mode share. Much of the work of structuring automobility space is determined by international regulations and interoperability requirements. In contrast, bicycle space lacks this international dimension, and is very largely governed at the local level, despite a long history of EU calls in favour of common standards as a means of increasing, or even consistently measuring, cycling modal share (EU 2004; ECF 2017). The construction of the legal street for the European Union as a whole, Birmingham, and Brussels is summarised in Table 5, where dashed lines reflect the same fluid demarcations as above; private property is not shown here due to space.

\section{Amsterdam}

Amsterdam is one of only two large cities in Europe (with Copenhagen) in which cycling has a dominant modal share. Significantly, the Netherlands as a whole has a high national modal share for cycling, accompanied by a widespread willingness to limit automobile space and speed. For example, the Netherlands was arguably the first

Table 5 The legal street across the EU, in Brussels and in Birmingham

\begin{tabular}{|c|c|c|c|c|c|}
\hline \multirow{2}{*}{$\begin{array}{l}\begin{array}{r}\text { Type of } \\
\text { Space }\end{array} \\
\text { Type } \\
\text { of Claim }\end{array}$} & \multicolumn{2}{|l|}{ Automobile space } & \multicolumn{2}{|l|}{ Bicycle space } & \multirow{2}{*}{$\begin{array}{l}\text { Pedestrian } \\
\text { and other } \\
\text { space }\end{array}$} \\
\hline & Circulatory space & $\begin{array}{l}\text { Dormant } \\
\text { space }\end{array}$ & $\begin{array}{l}\text { Circulatory } \\
\text { space }\end{array}$ & $\begin{array}{l}\text { Dormant } \\
\text { space }\end{array}$ & \\
\hline $\begin{array}{l}\text { Allocation } \\
\text { Mechanism }\end{array}$ & $\begin{array}{l}\text { Strong but } \\
\text { weakening - ending } \\
\text { through-traffic in city } \\
\text { centre is under } \\
\text { consideration; } \\
\text { emergency \& } \\
\text { disabled access } \\
\text { now routinely } \\
\text { separated from } \\
\text { other vehicle access } \\
\text { by technology }\end{array}$ & $\begin{array}{l}\text { Actively being } \\
\text { reduced, near } \\
\text { zero for new } \\
\text { developments; } \\
\text { historical } \\
\text { minimums } \\
\text { changed to } \\
\text { maximums }\end{array}$ & $\begin{array}{l}\text { Strong - a } \\
\text { comprehensive } \\
\text { system under } \\
\text { constant } \\
\text { redevelopment }\end{array}$ & $\begin{array}{l}\text { Strong - } \\
\text { growing } \\
\text { supply, but } \\
\text { informal } \\
\text { parking } \\
\text { extends into } \\
\text { pedestrian } \\
\text { space }\end{array}$ & $\begin{array}{l}\text { Strong but } \\
\text { under } \\
\text { pressure - } \\
\text { walkability } \\
\text { impacted by } \\
\text { spillover } \\
\text { bicycle } \\
\text {, parking and } \\
\text { car parking } \\
\text { I }\end{array}$ \\
\hline $\begin{array}{l}\text { Appropriation } \\
\text { Practice }\end{array}$ & $\begin{array}{l}\text { Weak - modal } \\
\text { share relatively low }\end{array}$ & $\begin{array}{l}\text { Weak - low } \\
\text { occupancy off- } \\
\text { street, high } \\
\text { on-street }\end{array}$ & $\begin{array}{l}\text { Strong - modal } \\
\text { share very high } \\
\text { and rising }\end{array}$ & $\begin{array}{l}\text { Strong- } \\
\text { very high } \\
\text { Occupancy } \\
\text { with } \\
\text { saturation at } \\
\text { peak times }\end{array}$ & $\begin{array}{l}\text { I Strong- } \\
\text { I relatively } \\
\text { I low modal } \\
\text { I share by EU } \\
\text { I standards } \\
\text { I due to } \\
\text { I cycling rate }\end{array}$ \\
\hline
\end{tabular}


European state to introduce a national car parking policy in 1988, in the form of the $\mathrm{ABC}$ scheme, which classified the national territory according to its accessibility by various modes, and limited car parking requirements where accessibility by bicycle or public transport was high (ECF 2018).

\section{Automobile circulatory space}

Automobile circulatory space in Amsterdam is governed by the city's new Agenda Amsterdam Autoluw (Gemeente Amsterdam 2019a), which sets out a role for the car as a city-wide mobility mode within limits on through-traffic and speed, as well as an overall commitment to reducing absolute traffic volumes.

\section{Automobile dormant space}

In Amsterdam, following decades of lock-in through parking minimums, the city has converted parking minimums to parking maximums, capping the total number of parking spaces such that new off-street provision will entail the removal of onstreet parking, and reducing parking provision in new-build neighbourhoods to very low levels (Gemeente Amsterdam 2019b). Instead of the routinized allocation of on-street dormant space for cars that produced a large amount of car space in the city up to the 1990s, the role of parking minimums as a constraint on the options available to public space decision-makers is now largely historical. ${ }^{12}$ There is no single approach or rationale to justify the retention or removal of a car parking space, and no single framework that governs or determines the allocation of open urban space (Gemeente Amsterdam 2019a, p. 57).

\section{Bicycle circulatory space}

Bicycle circulatory space has long been a backbone of mobility planning in Amsterdam, and its current policy builds on an already fine-grained network of segregated major cycleways and supporting bicycle lanes.

\section{Bicycle dormant space}

Amsterdam sets out a requirement that bicycle parking space within a given street should have a maximum occupation rate of $85 \%$, based on observation. Exceeding this limit triggers a procedure to increase dormant bicycle space. This provision supports a national building regulation, the Bouwbesluit, that requires off-street bicycle parking space to be provided in new buildings (Netherlands Government 2012). However, unlike the Bouwbesluit, the space claims emanating from observation of bicycle parking demand do not automatically impose a regulatory burden on private property owners, nor do they automatically entail the provision of dormant bicycle space in the immediate environment. Instead, these space claims prompt the city to consider allocating space nearby: it is increasingly understood that this may involve a walk to a neighbourhood off-street parking facility (buurtstalling) or large bicycle parking facility (fietsenstalling), since "the days of parking your bike in front of the door of your destination are over" ("B" interview, 17/01/20). 


\section{Pedestrian space}

A city-wide minimum width for pedestrian and wheelchair access on sidewalks is set at $1.8 \mathrm{~m}$. It is widely recognized that this minimum is insufficient in higher-traffic areas, particularly in the city's historic centre. There is also a consensus that the pedestrian space is frequently obstructed by other space uses, including dormant bicycles, as well as automobiles loading or parked.

In summary, Amsterdam's approach to space claims reveal that its ambitious decoupling of automobility lock-in on public space claims fits within a national framework of limitations on on-street car parking (in city centres), and widespread and longstanding bicycle parking minimums (everywhere). In contrast, while the EU contains several examples of visionary approaches to space claims at city level, very few of these fit within supportive national policies.

Instead, the city's Agenda sets out overall ambitions and decision-making frameworks that must be tested in and adapted to every street and case. Respondent B, an urban planner specialising in shared space at the City of Amsterdam, relates that the parking maximum for new-build neighbourhoods in the city, such as the Havenstad, is set at 1 (off-street) parking space per 5 dwellings, ${ }^{11}$ lower even than the current average for central Amsterdam (0.4 per dwelling) (Gemeente Amsterdam 2019a). The resulting development will be free of the presence of parked cars at street level. Even designated loading zones have been omitted, in favour of a physical design that permits loading vehicles to stop without completely obstructing traffic, but without the security of access provided by a demarcated loading area.

The legal street in Amsterdam is summarised in Table 6. In contrast to the diagrams for the EU as a whole, Brussels and Birmingham, it shows that bicycle space allocation mechanisms are strong; solid lines reflect a stable demarcation between bicycle and automobile space. As in the other cases, the boundaries between pedestrian and bicycle space are relatively fluid, but in the case of Amsterdam's high mode share for cycling, this results in significant incursion of parked bicycles into pedestrian space. In interviews, Amsterdam officials state that in the last 5 years, day-to-day decision-making has evolved away from a model that closely resembles the legal street - in which teams of personnel, organised by mode, articulated spatial claims through allocation mechanisms. This has meant an a priori weakening of these mechanisms as determinants of how space is distributed, in favour of a more contextual, case-by-case process in which officials haggle internally about space requirements. Arguably, the new process reflects a scarcity-based approach organised around the recognition that "the space between private properties is fixed" (“B” interview, 17/01/20).

\section{Discussion and conclusions}

The differences revealed in the legal streets for the cases above show that automobility space allocation mechanisms have been relatively strong all over the EU until the beginning of this century. Moreover, these mechanisms have been, and to a considerable extent remain, embedded in binding national policy in a majority of EU states. In contrast, bicycle space allocation mechanisms are largely absent at the international level,

${ }^{11}$ In comparison, parking minimums were set at 1.0 per dwelling, five times higher, as recently as 2011 (ITDP 2011) 
Table 6 The legal street in Amsterdam

\begin{tabular}{|c|c|c|c|c|c|}
\hline \multirow{2}{*}{$\begin{array}{r}\begin{array}{r}\text { Type of } \\
\text { Space }\end{array} \\
\text { Type } \\
\text { of Claim }\end{array}$} & \multicolumn{2}{|l|}{ Automobile space } & \multicolumn{2}{|l|}{ Bicycle space } & \multirow{2}{*}{$\begin{array}{l}\text { Pedestrian } \\
\text { and other } \\
\text { space }\end{array}$} \\
\hline & Circulatory space & $\begin{array}{l}\text { Dormant } \\
\text { space }\end{array}$ & $\begin{array}{l}\text { Circulatory } \\
\text { space }\end{array}$ & $\begin{array}{l}\text { Dormant } \\
\text { space }\end{array}$ & \\
\hline $\begin{array}{l}\text { Allocation } \\
\text { Mechanism }\end{array}$ & $\begin{array}{l}\text { Strong but } \\
\text { weakening - ending } \\
\text { through-traffic in city } \\
\text { centre is under } \\
\text { consideration; } \\
\text { emergency \& } \\
\text { disabled access } \\
\text { now routinely } \\
\text { separated from } \\
\text { other vehicle access } \\
\text { by technology }\end{array}$ & $\begin{array}{l}\text { Actively being } \\
\text { reduced, near } \\
\text { zero for new } \\
\text { developments; } \\
\text { historical } \\
\text { minimums } \\
\text { changed to } \\
\text { maximums }\end{array}$ & $\begin{array}{l}\text { Strong - a } \\
\text { comprehensive } \\
\text { system under } \\
\text { constant } \\
\text { redevelopment }\end{array}$ & $\begin{array}{l}\text { Strong - } \\
\text { growing } \\
\text { supply, but } \\
\text { informal } \\
\text { parking } \\
\text { extends into } \\
\text { pedestrian } \\
\text { space }\end{array}$ & $\begin{array}{l}\text { Strong but } \\
\text { I under } \\
\text { pressure - } \\
\text { I walkability } \\
\text { I impacted by } \\
\text { s spillover } \\
\text { I bicycle } \\
\text { I parking and } \\
\text { car parking }\end{array}$ \\
\hline $\begin{array}{l}\text { Appropriation } \\
\text { Practice }\end{array}$ & $\begin{array}{l}\text { Weak - modal } \\
\text { share relatively low }\end{array}$ & $\begin{array}{l}\text { Weak - low } \\
\text { occupancy off- } \\
\text { street, high } \\
\text { on-street }\end{array}$ & $\begin{array}{l}\text { Strong - modal } \\
\text { share very high } \\
\text { and rising }\end{array}$ & $\begin{array}{l}\text { Strong - } \\
\text { very high } \\
\text { Occupancy } \\
\text { with } \\
\text { saturation at } \\
\text { peak times }\end{array}$ & $\begin{array}{l}\text { I Strong - } \\
\text { I relatively } \\
\text { I low modal } \\
\text { I share by EU } \\
\text { I standards } \\
\text { I due to } \\
\text { I cycling rate }\end{array}$ \\
\hline
\end{tabular}

and at the national level, they are largely absent or, if they exist, largely advisory. Only at the level of towns, cities and city-regions are allocation mechanisms for bicycle space relatively widespread.

However, appropriation practices often tell a different story. The number of places in the EU in which cycling plays a significant role in everyday urban mobility ${ }^{13}$ is smaller still than the number of places with some level of protection for bicycle space claims (ECF 2018). This discrepancy points to the limitations of considering spatial allocation mechanisms, and the distribution of urban space more generally, as a proxy for the strength or weakness of urban mobility regimes. However, by simplifying and generalising complex spatial arrangements through the legal street framework, some clear differences emerge between high-cycling (Amsterdam) and aspirational cycling contexts (Brussels and Birmingham).

The first of these relates to the lock-in that automobility has historically enjoyed in terms of the strength and stability of its claims on public space. Decades of production of parking spaces, driven by parking minimum formulae, have produced an abundant supply of car parking space in western European cities, including Amsterdam. Because car journeys must start and end in a parking space, and because the built environment changes relatively slowly, this legacy allocation of space locks cities into automobility in a particularly obdurate way (Mäkinen et al. 2015). The legal street framework shows that this 'stock' of space should be contrasted with the 'flow' of current allocation mechanisms, which, even when they aim at radical transformation, tend to affect only new building and renovation projects. In Amsterdam, the flow of car parking space production has been attenuated rather than bolstered by national policy. It has also

\footnotetext{
${ }^{12}$ Pointing to this history, the Agenda contrasts 1970s photographs of iconic Amsterdam squares and streets packed with parked cars with the relatively car-free present, and sets out a vision for an equivalent transition by 2040 (Gemeente Amsterdam 2019a).
} 
been contested by strong and long-established bicycle space allocation mechanisms, including those requiring off-street bicycle parking in building regulations. In Brussels and Birmingham, car space allocation mechanisms have more fully monopolised open space until recently. In these cities, present-day transitions policies must therefore simultaneously reclaim car space and create an arena of competition between the dominant automobility regime and a relatively much weaker cycling system.

A second salient aspect is an institutional connection between urban space commodification, data, city revenue, and space allocation mechanisms. Through historical processes, car dormant space has become highly codified and commodified, creating a substantial market for the hourly, daily or annual rental of urban open space that generates revenue and data for cities. At the same time, this market is heavily distorted, particularly in the form of subsidised residents' parking permits, which constitute a large ongoing entitlement to urban open space for car storage. In contrast, bicycle dormant space is mostly operated on a cost-free basis, especially in Amsterdam, where even off-street bicycle parking tends to be free (for the first $24 \mathrm{~h}$ of every use); it costs rather than generates revenue.

In Amsterdam, despite decades of successful cycling governance, systematic data collection and monitoring of on-street bicycle parking is a recent phenomenon. In contrast to cars, interviewed officials agree that Amsterdam has "almost no regulatory tools to control bicycles" ("B" interview, 17/01/20), and it has only recently become possible to designate districts in the city where informal bicycle parking is banned (meaning that all bicycles must be parked in formal infrastructure, on pain of removal) ("C" interview, 21/01/20; "D" interview, 29/11/2019). An institutional disparity therefore exists between licensed drivers in registered automobiles occupying geometrically codified parking spaces, and the usually anonymous cyclist riding an unregistered bicycle, who most often parks informally in a space shared with other uses (Petzer et al. 2019).

In tension with this difference is the fact that both car and bicycle parking make overlapping, identical claims on the finite square metres of urban open space, in Amsterdam as in Brussels and Birmingham. The legal street framework presents the allocation mechanisms that express these claims as strong and weak, reflecting the relative institutional power of the automobility and cycling regimes respectively. The framework also underlines that, in all three cities, these mechanisms convert the common stock of urban open space into a commodified rental market (for car parking) and a very weakly codified, mostly uncommodified 'commons' (for bicycle parking). In all three cases, however, the bicycle 'commons' forms part of the residual pedestrian commons, which accommodates an intense and growing mix of mobility modes and other space uses.

In transitions terms, the legal street framework enables comparison between mobility systems through the lens of an essential, rivalrous resource. This resource lens sheds light on hitherto underdeveloped constraints that the finitude and scarcity of urban open space impose on sustainable mobility transitions. Some of these insights are applicable to any common-pool resource (Parker and Johansson 2011a, b), but others are unique to the urban context. Thus, while transitions research has highlighted the

\footnotetext{
${ }^{13}$ Comparison of cycling and walking data across EU member states is very challenging (EC DG MOVE 2017), but national figures from a 2014 survey suggests that cycling mode share was then under $10 \%$ in 21 out of 28 member states (Eurobarometer 2014).
} 
obduracy of the built environment, we contribute a distinction between that environment based on its division into two kinds of space (commodified, and commons), with different kinds of obduracy. Transitions scholars have likewise extensively described the lock-in that benefits automobility. However, the scarcity approach to urban open space suggests that, in many cases, automobility lock-in on its own spatial requirements amounts to a lock-out of other, subordinate mobility modes as well as other urban activities. This relationship is emphasised by a common quantitative measure that can directly compare the space-efficiency of one car parking space with $n$ bicycle parking spaces, and the prominence of 'space efficiency' arguments in policies for the EU (EC DG MOVE 2019), Amsterdam (Gemeente Amsterdam 2019b), Brussels (Bruxelles Mobilité 2017) and Birmingham (Birmingham City Council 2019). By the same token, the scarcity approach suggests that weakening the allocation mechanisms that produce car space, or weakening appropriation mechanisms (for example, banning sidewalk car parking), could in itself be a powerful (albeit institutionally and politically very challenging) means of countering car lock-in.

In addition, a mobility transitions framework that foregrounds space offers an important counterpoint to more technology-focused transitions research. Our findings suggest that efforts to innovate more sustainable and safe propulsion or driving systems for cars will not, in themselves, address the space allocation imperatives locked-in by cars, emphasising an important distinction among mobility modes that are widely labelled 'sustainable'. Our focus on streets in the aggregate offers a contrast to the more typical focus on specific project sites, or new-build city districts, in scholarship such as that reviewed by Nielsen and Farrelly in their study of conceptualisations of urban physicality from a transitions perspective (Nielsen and Farrelly 2019).

For transitions research as a whole, our framework provides a potentially useful means of highlighting space allocation within place-based, urban, and geographical transitions research, and more broadly, as an institutional aspect of urban mobility regimes that can be assessed at distinct analytical and spatial scales.

Our study is limited by the generalisations required to condense parking and landuse policies for the purposes of comparison in our legal street framework. The legal street, as a notional cross-section of a street, is useful as a representation of the cumulative effect that streets have in shaping mobility transitions (Henderson 2009, 2015). It does, however, ignore the heightened politics of intersections (Prytherch 2015), and relative differences within the city - for example, between centre and periphery. We also leave open the excellent question posed by Nello-Deakin (2019) and Mullen et al. (2014), as to how a fair distribution of road space between modes could be determined or identified; we focus only on the stated aims of our case study sites. Further research is needed to explore the question of how stubborn physical aspects of space interact with relational conceptualisations of space (Coenen et al. 2012), and more empirical work must be done to develop and test the concepts of space claims, allocation mechanisms and appropriation practices in other contexts. 


\section{Authors' contributions}

BP proposed the initial concept as part of BP's doctoral research. GV, AW and BP developed this to proposal stage in the course of approximately 30 meetings, with GV particularly responsible for the development of urban planning and mobility perspectives and AW particularly responsible for aligning the proposal with the state of the art of transitions research. AW contributed an initial and revised methodology. GV contributed multiple revisions of the legal street framework in its relation to empirical practice. BP conducted interviews and consolidated the research into the first and second submissions. The authors read and approved the final manuscript

\section{Funding}

Not applicable.

\section{Availability of data and materials}

All data used are from publicly available cited sources, except for interviews.

\section{Competing interests}

Not applicable.

Received: 8 April 2020 Accepted: 1 January 2021

Published online: 17 February 2021

\section{References}

Adam L, Jones T, te Brömmelstroet M. Planning for cycling in the dispersed city: establishing a hierarchy of effectiveness of municipal cycling policies. Transportation. 2018; https://doi.org/10.1007/s11116-018-9878-3.

Affolderbach J, Schulz C. Mobile transitions: Exploring synergies for urban sustainability research. Urban Stud. 2016;53:1942-57 https://doi.org/10.1177/0042098015583784.

Aldred R, Jungnickel K. Matter in or out of place? Bicycle parking strategies and their effects on people, practices and places. Soc Cult Geogr. 2013;14:604-24 https://doi.org/10.1080/14649365.2013.790993.

Attias D, editor. The Automobile Revolution. Cham: Springer International Publishing; 2017.

Avelino F, Grin J, Pel B, Jhagroe S. The politics of sustainability transitions. J Environ Policy Plan. 2016;18:557-67 https://doi. org/10.1080/1523908X.2016.1216782

Banister D. Unsustainable transport city transport in the new century. London: Routledge; 2005.

Banister D. The sustainable mobility paradigm. Transp Policy. 2008;15:73-80 https://doi.org/10.1016/.tranpol.2007.10.005.

Barrington-Leigh C, Millard-Ball A. Global trends toward urban street-network sprawl. Proc Natl Acad Sci. 2020;117:1941-50 https://doi.org/10.1073/pnas.1905232116.

Barter PA. A parking policy typology for clearer thinking on parking reform. Int J Urban Sci. 2015;19:136-56 https://doi.org/10. 1080/12265934.2014.927740.

Becker S, Moss T, Naumann M. The Importance of Space: Towards a Socio-Material and Political Geography of Energy Transitions. In: Gailing L, Moss T, editors. Conceptualizing Germany's Energy Transition. London: Palgrave Macmillan UK 2016. p. 93-108.

Birmingham City Council. Birmingham Parking: Supplementary Planning Document. Birmingham: Consultation Draft; 2019 Birmingham City Council (2020a) Birmingham Transport Plan (Draft).

Birmingham City Council. Emergency Birmingham Transport Plan: A low carbon, clean air recovery after COVID-19. UK: Birmingham; 2020b.

Borch C. Urban Commons: Rethinking the City. 1st ed. London: Routledge; 2015.

Bridge G, Bouzarovski S, Bradshaw M, Eyre N. Geographies of energy transition: Space, place and the low-carbon economy. Energy Policy. 2013;53:331-40 https://doi.org/10.1016/j.enpol.2012.10.066.

Brown MG. Access, Property and American Urban Space. London: Routledge; 2016.

Bruxelles Environnement (2019) Mieux se déplacer à Bruxelles: Des idées simples qui donnent envie de bouger.

Bruxelles Mobilité (2016a) Le partage de l'espace public en Région de Bruxelles-Capitale.

Bruxelles Mobilité (2016b) Espace pour le transport public.

Bruxelles Mobilité. Diagnostic de mobilité en Région bruxelloise. Brussels: Service public régional de Bruxelles; 2017.

Bruxelles Mobilité. Plan régional de mobilité 2020-2030: Plan stratégique et opérationnel. Brussels: Bruxelles Mobilité; 2020.

Buiter H. Constructing Dutch Streets. In: Urban Machinery: Inside Modern European Cities. Cambridge: MIT Press; 2008.

Bulkeley H, Broto VC, Hodson M, Marvin S. Cities and low carbon transitions. London: Routledge; 2010.

Bulkeley H, Castán Broto V, Maassen A. Low-carbon Transitions and the Reconfiguration of Urban Infrastructure. Urban Stud. 2014;51:1471-86 https://doi.org/10.1177/0042098013500089.

Caprotti F, Harmer N. Spatialising Urban Sustainability Transitions: Eco-cities, Multilevel Perspectives and the Political Ecology of Scale in the Bohai Rim, China. In: Frantzeskaki N, Broto VC, Coenen L, Loorbach D, editors. Urban Sustainability Transitions. Abingdon: Taylor \& Francis; 2017

Castán Broto V. Contradiction, intervention, and urban low carbon transitions. Environ Plan Soc Space. 2015;0:0-0 https://doi. org/10.1068/d13050p.

Chatterton P. Building transitions to post-capitalist urban commons. Trans Inst Br Geogr. 2016;41:403-15 https://doi.org/10. 1111/tran.12139.

Cidell J, Prytherch D, editors. Transport, mobility, and the production of urban space. New York; London: Routledge; 2015.

CIHT. Manual for Streets 2. London: Chartered Institute of Highways \& Transportation; 2010.

Coenen L, Benneworth P, Truffer B. Toward a spatial perspective on sustainability transitions. Res Policy. 2012;41:968-79 https://doi.org/10.1016/j.respol.2012.02.014.

Coenen L, Truffer B. Places and Spaces of Sustainability Transitions: Geographical Contributions to an Emerging Research and Policy Field. Eur Plan Stud. 2012;20:367-74 https://doi.org/10.1080/09654313.2012.651802.

CROW. Aanbevelingen voor verkeersvoorzieningen binnen de bebouwde kom. Ede: CROW; 2012.

CROW. Design Manual for Bicycle Traffic. Utrecht: CROW; 2016. 
Crozet Y, Santos G, Coledfy J. Shared Mobility, MaaS and the Regulatory Challenges of Urban Mobility. Brussels: Cerre | Centre on Regulation in Europe; 2019.

De Muelenaere M. Bruxelles a besoin de plus d'espace public: Le Soir; 2020. 15/05/2020. Available from: https://plus.lesoir. be/301215/article/2020-05-15/bruxelles-besoin-de-plus-despace-public.

EC DG MOVE. Support study on data collection and analysis of active modes use and infrastructure in Europe: Final Report. Brussels: European Commission Directorate-General for Mobility and Transport; 2017.

EC DG MOVE. Transport in the European Union: Current Trends and Issues. Brussels: European Commission DirectorateGeneral for Mobility and Transport; 2019.

ECF. EU Cycling Strategy: Recommendations for Delivering Green Growth and an Effective Mobility System in 2030. Brussels: European Cyclists' Federation; 2017.

ECF. Making Buildings Fit for Sustainable Mobility: Comparing Regulations for Off-Street Bicycle and Car Parking in Europe. Brussels: European Cyclists' Federation; 2018.

Emanuel M. Monuments of Unsustainability: Planning, Path Dependence, and Cycling in Stockholm. In: Oldenziel R, Trischler H, editors. Cycling and Recycling. New York: Berghahn Books; 2016. p. 101-24.

Epprecht N, von Wirth T, Stünzi C, Blumer YB. Anticipating transitions beyond the current mobility regimes: How acceptability matters. Futures. 2014;60:30-40 https://doi.org/10.1016/j.futures.2014.04.001.

EU. Urban Design for Sustainability: Final Report of the Working Group on Urban Design for Sustainability to the European Union Expert Group on the Urban Environment. Vienna: EU Working Group on Urban Design for Sustainability; 2004.

EU DG Mobility \& Transport. European Urban Mobility: Policy Context. EU Directorate-General for Mobility and Transport: Directorate - Investment, Innovative \& Sustainable Transport. Brussels: Unit B4 - Sustainable \& Intelligent Transport; 2017.

EU Partnership on Urban Mobility (2017) Urban Agenda for the European Union: Orientation Paper.

Eurobarometer. Quality of Transport. Brussels: European Commission Directorate-General for Mobility and Transport; 2014.

European Parking Association. The Scope of Parking in Europe: Data Collection by the European Parking Association. Cologne: European Parking Association; 2013.

Fiorito R, Kollintzas T. Public goods, merit goods, and the relation between private and government consumption. Eur Econ Rev. 2004;48:1367-98.

Foster S, laione C. The city as a commons. Yale Law Policy Rev. 2016;34:281.

Frantzeskaki N, Broto VC, Coenen L, editors. Urban Sustainability Transitions, First Edition. New York: Routledge; 2017.

Geels F. The role of cities in technological transitions: analytical clarifications and historical examples, in: Bulkeley, H., Castán Broto, V., Hodson, M., Marvin, S. (Eds.), Cities and Low Carbon Transitions. Routledge: Routledge Studies in Human Geography; 2010, pp. 29-44.

Geels FW. The dynamics of transitions in socio-technical systems: a multi-level analysis of the transition pathway from horsedrawn carriages to automobiles (1860-1930). Technol Anal Strateg Manag. 2005;17:445-76 https://doi.org/10.1080/ 09537320500357319.

Geels FW. A socio-technical analysis of low-carbon transitions: introducing the multi-level perspective into transport studies. J Transp Geogr. 2012;24:471-82 https://doi.org/10.1016/j.jtrangeo.2012.01.021.

Geels FW, Dudley G, Kemp R. Findings, Conclusions and Assessments of Sustainability Transitions in Automobility. In: Geels FW, editor. Automobility in Transition? A Socio-Technical Analysis of Sustainable Transport. New York; London: Routledge; 2012. p. 335-73.

Gemeente Amsterdam (2016) Handboek Handhaving Fietsparkeren.

Gemeente Amsterdam. Meerjarenplan Fiets 2017-2022: Gemeente Amsterdam; 2017a.

Gemeente Amsterdam. Gemeente Amsterdam Nota Deelfiets (concept). Amsterdam: Gemeente Amsterdam; 2017b.

Gemeente Amsterdam. Agenda Amsterdam Autoluw: Amsterdam maakt ruimte: Gemeente Amsterdam; 2019a.

Gemeente Amsterdam. Inrichtingsprincipes voor een autoluwe stad (Bijlage: Agenda Amsterdam Autoluw): Verkeer \& Openbare Ruimte; 2019b.

Gemeente Amsterdam. Deelmobiliteit, kansen voor de stad: Beleid voor het delen van schone vervoermiddelen anders dan de auto: Verkeer \& Openbare Ruimte; 2019c.

Ghosh D, Sengers F, Wieczorek AJ, et al. Urban mobility experiments in India and Thailand: Exp City Routledge Oxon; 2016. p. $122-36$.

Gössling S, Choi AS. Transport transitions in Copenhagen: Comparing the cost of cars and bicycles. Ecol Econ. 2015;113:10613 https://doi.org/10.1016/j.ecolecon.2015.03.006.

Gössling S, Schröder M, Späth P, Freytag T. Urban Space Distribution and Sustainable Transport. Transp Rev. 2016;36:659-79 https://doi.org/10.1080/01441647.2016.1147101.

Groote JD, Ommeren JV, Koster HRA. Car ownership and residential parking subsidies: Evidence from Amsterdam. Econ Transp. 2016;6:25-37 https://doi.org/10.1016/j.ecotra.2016.07.001.

Gunn S. Ring road: Birmingham and the collapse of the motor city ideal in 1970s Britain. Hist J. 2018:61:227-48.

Hamedinger A. The Mobility and/or Fixity of Urban and Planning Policies - The Role of Divergent Urban Planning Cultures. Eur Spat Res Policy. 2014;21:23-37 https://doi.org/10.2478/esrp-2014-0003.

Hansen T, Coenen L. The geography of sustainability transitions: Review, synthesis and reflections on an emergent research field. Environ Innov Soc Transit. 2015;17:92-109 https://doi.org/10.1016/j.eist.2014.11.001.

Hebbert M. Engineering, Urbanism and the Struggle for Street Design. J Urban Des. 2005;10:39-59 https://doi.org/10.1080/ 13574800500062361.

Heinen E, Buehler R. Bicycle parking: a systematic review of scientific literature on parking behaviour, parking preferences, and their influence on cycling and travel behaviour. Transp Rev. 2019:1-27 https://doi.org/10.1080/01441647.2019. 1590477.

Henderson J. The politics of mobility: De-essentializing automobility and contesting urban space. In: Conley J, Tigar McLaren A, editors. Car Troubles: Critical Studies of Automobility and Auto-Mobility. Burlington: Ashgate; 2009. p. 147-64.

Henderson J. From Climate Fight to Street Fight: The Politics of Mobility and the Right to the City. In: Cidell J, Prytherch D, editors. Transport, mobility, and the production of urban space. New York; London: Routledge; 2015. p. 101-16. 
Henry A, Ermans T, de Smet d'Olbecke F. Un retour de la bicyclette, aussi à Bruxelles ? Bruss Stud. 2020;144. https://doi.org/ 10.4000/brussels.4826.

Hirschhorn F, Paulsson A, Sørensen CH, Veeneman W. Public transport regimes and mobility as a service: Governance approaches in Amsterdam, Birmingham, and Helsinki. Transp Res Part Policy Pract. 2019;130:178-91.

Hodson M, Marvin S, Robinson B, Swilling M. Reshaping Urban Infrastructure: Material Flow Analysis and Transitions Analysis in an Urban Context. J Ind Ecol. 2012;16:789-800 https://doi.org/10.1111/j.1530-9290.2012.00559.x.

Hoffmann S, Weyer J, Longen J. Discontinuation of the automobility regime? An integrated approach to multi-level governance. Transp Res Part Policy Pract. 2017;103:391-408 https://doi.org/10.1016/j.tra.2017.06.016.

Hubert M, Corijn E, Neuwels J, et al. Du « grand piétonnier » au projet urbain : atouts et défis pour le centre-ville de Bruxelles: Note de synthèse BSI. Bruss Stud. 2017; https://doi.org/10.4000/brussels.1551.

ITDP. Europe's Parking U-Turn: From Accommodation to Regulation. New York: Institute for Transportation \& Development Policy; 2011.

Jensen JS, Lauridsen EH, Fratini CF, Hoffmann B. Harbour bathing and the urban transition of water in Copenhagen: junctions, mediators, and urban navigations. Environ Plan A. 2015:47:554-70.

Jones IH. Road Space Allocation: The Intersection of Transport Planning, Governance and Infrastructure; 2014.

Jones P. A comprehensive basis for determining the allocation of urban street space. In: 14th World Conference on Transport Research: Shanghai; 2016.

Latour B. Science in action: How to follow scientists and engineers through society. Cambridge: Harvard University Press; 1987.

Lecy JD, Beatty KE. Representative literature reviews using constrained snowball sampling and citation network analysis. SSRN Electron J. 2012, 2012. https://doi.org/10.2139/ssrn.1992601.

Levin-Keitel M, Mölders T, Othengrafen F, Ibendorf J. Sustainability Transitions and the Spatial Interface: Developing Conceptual Perspectives. Sustainability. 2018;10:1880 https://doi.org/10.3390/su10061880.

Longhurst J. Bike Battles: A History of Sharing the American Road. Seattle: University of Washington Press; 2015.

Loorbach DA. Governance of urban sustainability transitions. Berlin, Heidelberg, New York: Springer; 2016.

Magalhães CD, Carmona M. Innovations in the Management of Public Space: Reshaping and Refocusing Governance. Plan Theory Pract. 2006;7:289-303 https://doi.org/10.1080/14649350600841461.

Mäkinen K, Kivimaa P, Helminen V. Path creation for urban mobility transitions: Linking aspects of urban form to transport policy analysis. Manag Environ Qual Int J. 2015;26:485-504 https://doi.org/10.1108/MEQ-07-2014-0115.

May X. The debate regarding the number of company cars in Belgium. Bruss Stud. 2017;8.

Mingardo G, van Wee B, Rye T. Urban parking policy in Europe: A conceptualization of past and possible future trends. Transp Res Part Policy Pract. 2015;74:268-81 https://doi.org/10.1016/j.tra.2015.02.005.

Monstadt J. Conceptualizing the Political Ecology of Urban Infrastructures: Insights from Technology and Urban Studies. Environ Plan Econ Space. 2009;41:1924-42 https://doi.org/10.1068/a4145.

Mullen C, Tight M, Whiteing A, Jopson A. Knowing their place on the roads: What would equality mean for walking and cycling? Transp Res Part Policy Pract. 2014;61:238-48 https://doi.org/10.1016/j.tra.2014.01.009.

Nello-Deakin S. Is there such a thing as a 'fair' distribution of road space? J Urban Des. 2019:1-17 https://doi.org/10.1080/ 13574809.2019.1592664.

Netherlands Government (2012) Integrale nota van toelichting van Bouwbesluit 2012.

Newman P, Kenworthy J. Sustainability and cities: overcoming automobile dependence. Washington, DC: Island Press; 1999.

Nielsen J, Farrelly MA. Conceptualising the built environment to inform sustainable urban transitions. Environ Innov Soc Transit. 2019;33:231-48 https://doi.org/10.1016/j.eist.2019.07.001.

Nieuwstraten B. Fietsdelen in de regio Amsterdam. Amsterdam: Vervoerregio Amsterdam; 2019.

Nikolaeva A. From Constructed Scarcity and Mobility Austerity towards Mobility Commons? In: Living Mobil. Transit; 2017. http://livinginthemobilitytransition.forumviesmobiles.org/2016/11/23/from-constructed-scarcity-and-mobility-austeritytowards-mobility-commons/. Accessed 4 Jan 2017.

Norton PD. Fighting traffic: the dawn of the motor age in the American city. Cambridge: MIT Press; 2011.

Oldenziel R, de la Bruhèze AA. Contested spaces: Bicycle lanes in urban Europe, 1900-1995. Transfers. 2011;1:29-49.

Parker $P$, Johansson M. The uses and abuses of Elinor Ostrom's concept of commons in urban theorizing; 2011 a. p. 17.

Parker $P$, Johansson M. The uses and abuses of Elinor Ostrom's concept of commons in urban theorizing. In: International Conference of the European Urban Research Association, Cities without Limits, 23-25 June 2011. Copenhagen; 2011 b. http://urn.kb.se/resolve?urn=urn:nbn:se:mau:diva-10925.

Petzer BJM, Wieczorek AJ, Verbong GPJ. Making sense of Cycling-as-a-Service in the Netherlands: a combined business models and transitions approach. Environ Innov Soc Transit. 2019; https://doi.org/10.1016/j.eist.2019.09.001.

Philippopoulos-Mihalopoulos A, FitzGerald S. From Space Immaterial: The Invisibility of the Lawscape. Griffith Law Rev. 2008; 17:438-53 https://doi.org/10.1080/10383618.2008.10854618.

Prytherch D. Rules of the Road: Choreographing Mobility in the Everyday Intersection. In: Cidell J, Prytherch D, editors. Transport, mobility, and the production of urban space. New York; London: Routledge; 2015. p. 45-62.

Prytherch D. Law, Engineering, and the American right-of-way. New York: Springer Science+Business Media; 2018.

Pucher J, Buehler R. Making Cycling Irresistible: Lessons from The Netherlands, Denmark and Germany. Transp Rev. 2008;28: 495-528 https://doi.org/10.1080/01441640701806612.

Raven R, Schot J, Berkhout F. Space and scale in socio-technical transitions. Environ Innov Soc Transit. 2012;4:63-78 https:// doi.org/10.1016/j.eist.2012.08.001.

Région de Bruxelles-Capitale (2007) Brussels-Capital Region (bike): Titre II - Normes d'Habitabilite des Logements, Art. 17 (French). Ministère de la Région de Bruxelles-Capitale Administration de I'Aménagement du Territoire et du Logement, Brussels.

Reid C. How a Belgian port city inspired Birmingham's car-free ambitions. Guardian, vol. 2020; 2020a. Available at: https://www.theguardian.com/environment/2020/jan/20/how-a-belgian-port-city-inspired-birminghams-car-freeambitions.

Reid C (2020b) Boost For Cycling And Walking In Birmingham's Pandemic Emergency Transport Plan. Forbes, 14/05/2020. Available at: https://www.forbes.com/sites/carltonreid/2020/05/14/boost-for-cycling-and-walking-in-birminghams-postpandemic-emergency-transport-plan/\#6d874e017fae. 
Rohracher H, Späth P. From Building Small Urban Spaces for a Car-Free life to Challenging The Global Regime of Automobility: Cases from Vienna and Freiburg. In: Urban Sustainability Transitions, First Edition. New York: Routledge, Taylor \& Francis Group; 2017a.

Rohracher H, Späth P. Cities as Arenas of Low-Carbon Transitions: Friction Zones in the Negotiation of Low-Carbon Futures. In: Urban Sustainability Transitions, First Edition. New York: Routledge, Taylor \& Francis Group; 2017b.

Schilling MA. Technological lockout: An integrative model of the economic and strategic factors driving technology success and failure. Acad Manage Rev. 1998;23:267-84.

Schipper F. Driving Europe: Building Europe on roads in the twentieth century. Amsterdam: Amsterdam University Press; 2008.

Schipper F, Schot J. Infrastructural Europeanism, or the project of building Europe on infrastructures: an introduction. Hist Technol. 2011;27:245-64 https://doi.org/10.1080/07341512.2011.604166.

Sengers F, Raven R. Toward a spatial perspective on niche development: The case of Bus Rapid Transit. Environ Innov Soc Transit. 2015;17:166-82 https://doi.org/10.1016/j.eist.2014.12.003

Sheller M, Urry J. Mobilizing the new mobilities paradigm. Appl Mobilities. 2016;1:10-25 https://doi.org/10.1080/23800127. 2016.1151216

Shill GH. Should Law Subsidize Driving? University of lowa Legal Studies Research Paper Series. University of lowa College of Law; 2019. http://ssrn.com/abstract=3345366.

Shoup D. The high cost of free parking. Abingdon: Routledge; 2011

Shoup D. The high cost of free parking: Updated edition. Abingdon: Routledge; 2017.

Spinney J. Fixing Mobility in the Neoliberal City: Cycling Policy and Practice in London as a Mode of Political-Economic and Biopolitical Governance. Ann Am Assoc Geogr. 2016;106:450-8.

Spurling N. Dormant vehicles: Inverting urban mobility futures. Land Use Policy. 2019:S026483771831367X https://doi.org/10. 1016/j.landusepol.2019.02.031.

UK DfT. Manual for Streets. London: Telford; 2007.

UN (1968) Vienna Convention on Road Traffic (amended 1993, 2006).

UN Habitat (2013) Planning and Design for Sustainable Urban Mobility: Policy Directions: Global Report on Human Settlements.

Urry J. The 'System' of Automobility. Theory Cult Soc. 2004;21:25-39 https://doi.org/10.1177/0263276404046059.

van der Spek SC, Scheltema N. The importance of bicycle parking management. Res Transp Bus Manag. 2015;15:39-49 https://doi.org/10.1016/j.rtbm.2015.03.001

Van Zeebroeck B, Charles J. Impact et potentiel de l'usage du vélo sur l'économie et l'emploi en Région de Bruxelles-Capitale: Les effets directs et indirects de l'usage du vélo en 2002, 2012 et 2020. Brussels: Pro Velo R\&D; 2014.

Velo P. Observation du vélo en région de Bruxelles Capitale: Comptages et analyse des données, Rapport 2017. Brussels: Pro Velo; 2017.

Verkade T (2019) Het is tijd om de straat terug te geven aan fietsers en voetgangers. De Correspondent, 14/01/2019. Available at: https:/ decorrespondent.n//8777/het-is-tijd-om-de-straat-terug-te-geven-aan-fietsers-en-voetgangers/4274968021687-51ad45e6.

von Schönfeld KC, Bertolini L. Urban streets: Epitomes of planning challenges and opportunities at the interface of public space and mobility. Cities. 2017;68:48-55 https://doi.org/10.1016/j.cities.2017.04.012.

Ward K, Jonas AE, Miller B, Wilson D. The Routledge Handbook on Spaces of Urban Politics. Abingdon, Oxon; New York: Routledge; 2018.

Wells $\mathrm{P}$, Xenias D. From 'freedom of the open road' to 'cocooning': Understanding resistance to change in personal private automobility. Environ Innov Soc Transit. 2015;16:106-19 https://doi.org/10.1016/.jeist.2015.02.001.

Whitmarsh L. How useful is the Multi-Level Perspective for transport and sustainability research? J Transp Geogr. 2012;24:4837 https://doi.org/10.1016/j.jtrangeo.2012.01.022.

Wieczorek AJ, Raven R, Berkhout F. Transnational linkages in sustainability experiments: A typology and the case of solar photovoltaic energy in India. Environ Innov Soc Transit. 2015;17:149-65.

Wolfram, M., Frantzeskaki, N., Maschmeyer, S., 2016. Cities, systems and sustainability: status and perspectives of research on urban transformations. Current Opinion in Environmental Sustainability 22, 18-25. https://doi.org/10.1016/j.cosust.2017.01.014.

Yin RK. Case Study Research Design and Methods. 5th ed. Thousand Oaks: SAGE Publications; 2014.

Zijlstra T, Avelino F. A Socio-Spatial Perspective on the Car Regime. In: Geels FW, Kemp R, Dudley G, Lyons G, editors. Automobility in Transition? A Socio-Technical Analysis of Sustainable Transport. London: Routledge; 2012.

\section{Publisher's Note}

Springer Nature remains neutral with regard to jurisdictional claims in published maps and institutional affiliations.

Ready to submit your research? Choose BMC and benefit from:
- fast, convenient online submission
- thorough peer review by experienced researchers in your field
- rapid publication on acceptance
- support for research data, including large and complex data types
- gold Open Access which fosters wider collaboration and increased citations
- maximum visibility for your research: over 100M website views per year
At BMC, research is always in progress.
Learn more biomedcentral.com/submissions

